Egyptian J. Anim. Prod.,Vol. 31, Supplement Issue, Nov.(1994):361-371.

\title{
EFFECT OF HEAT STRESS AND DIETARY ROUGHAGE LEVEL ON RUMEN FUNCTION, NUTRIENT UTILIZATION AND WATER TURNOVER BY NATIVE EGYPTIAN SHEEP
}

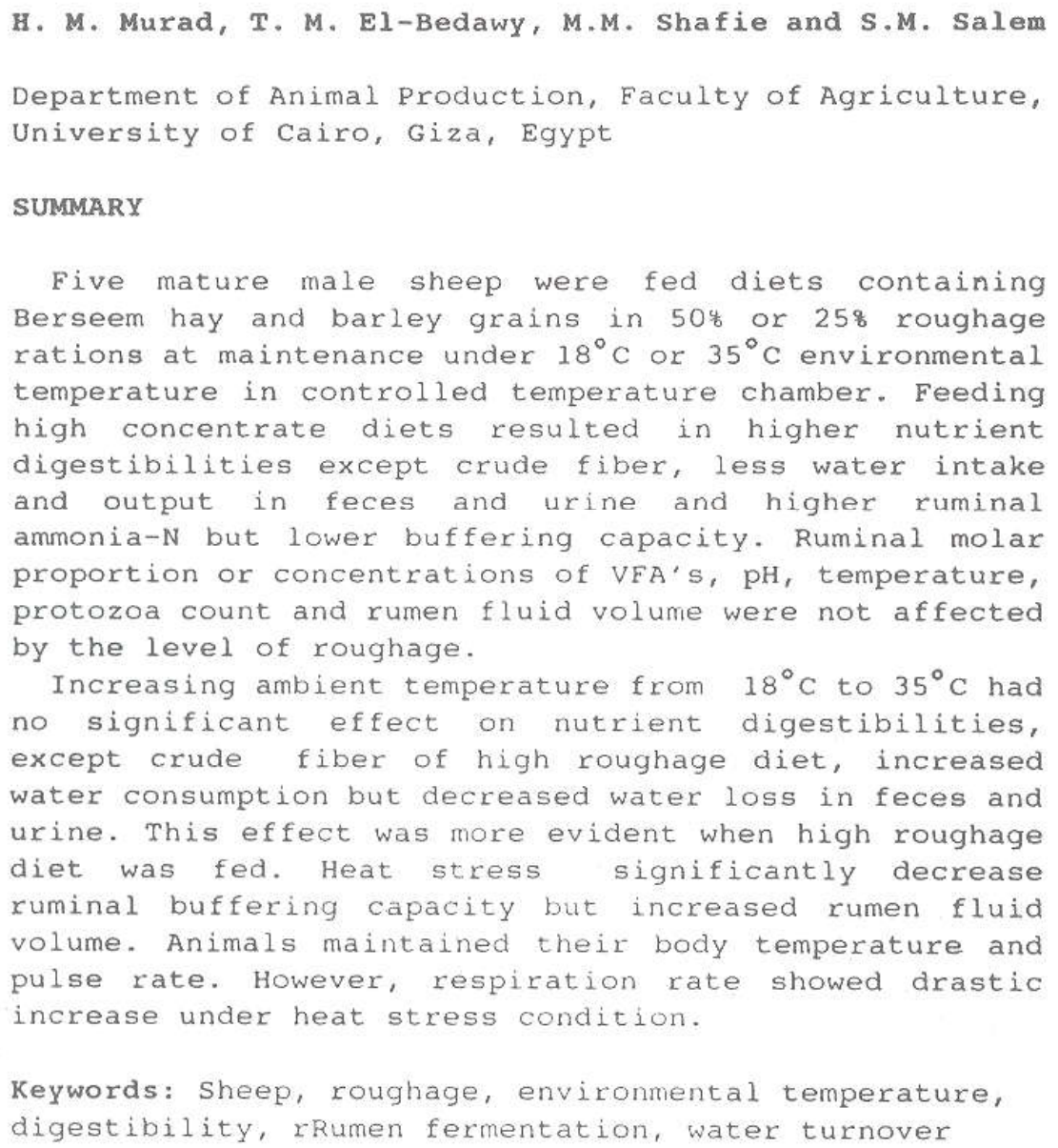


stress of high environmental temperature and the low quality feeds, particularly in the hot dry summer. These stressful conditions lead to lower feed intake and poor performance. Chaiyabuter et al. (1987) suggested that rumen fermentation may be influenced also by the level of roughage intake as well as environmental temperature.

The availability of water and its intake, turnover and output is of great consideration under hot conditions in relation with heat dissipation from the animal's body through water vaporization from the body and respiration surfaces. This case is apt to affect feed intake and nutrient utilization. Thus the availability of sufficient feed and its type and nutritive value are limiting factor in the success thrive of the animal.

During summer season in Egypt, animals are faced by such adverse environmental conditions, suffering from heat stress along with poor nutritional conditions. The objective of this study was to evaluate the effects of. heat stress and roughage level on rumen fermentation, nutrient utilization and water turnover by local sheep fed at the maintenance allowance.

\section{MATERIALS AND METHODS}

Five mature ossimi x Rahmani crossbred rams averaged $50 \mathrm{Kg}$ body weight fitted with ruminal cannula were used in Latin square design The dietary factor was roughage level ( $1: 1$ and $3: 1$ roughage : concentrate) through diets containing Berseem hay (IFN 1-01-340) and barley grains (IFN 4-00-549). Chemical composition of the experimental rations is shown in Table 1. The environmental factor was ambient temperature $118^{\circ} \mathrm{C}$ and $35^{\circ} \mathrm{C}$ ). Animals were fed a constant dry matter within each roughage level, being $910 \mathrm{~g} / \mathrm{head} / \mathrm{day}$ for $\mathrm{high}$ roughage diets and $770 \mathrm{~g} / \mathrm{head} / \mathrm{day}$ from low roughage one to cover their maintenance (NRC, 1975). Water was offered ad. 1ib. twice a day at 11:00 and 17:00 and water consumption was recorded.

Animals were individually housed in metabolism crates in controlled heat temperature chambers for 31 days under each heat condition, 21 day-preliminary, 7 day-collection period for digestibility assessment, 2 days rumen fluid sampling and one day to estimate rumen fluid volume. 
Table 1. Chemical composition of experimental diets.

\begin{tabular}{lcr}
\hline \multirow{2}{*}{ Item } & \multicolumn{2}{c}{ Roughage: Concentrate ratio } \\
\cline { 2 - 3 } & $(1: 1)$ & $(1: 3)$ \\
\hline Dry matter (DM), \& & 91.87 & 91.22 \\
Dry matter composition, 8 & \\
Organic matter (OM) & 91.22 & 93.49 \\
Crude protein (CP) & 14.08 & 13.23 \\
Ether extract (EE) & 3.20 & 3.62 \\
Crude fiber (CF) & 18.20 & 11.30 \\
N-free extract (NFE) & 55.74 & 65.34 \\
Ash & 6.51 & -8.78 \\
\hline
\end{tabular}

Chemical composition of feed and feces was determined according to A.O.A.C. (1975). Rumen samples were collected within two successive days following the digestion trail at $2,4,6,8$ and 24 hrs post-feeding. Rumen $\mathrm{pH}$ and temperature, ammonia nitrogen concentrations (Conway 1962), concentration of total volatile fatty acids (Kromann et al., 1967), molar proportions of volatile fatty acids (Erwin et al., 1961), buffering capacity (Nicholson et al., 1963), protozoa count (El-Saifi, 1969) and rumen fluid volume using Lithium sulphate (Mangan and Wright 1968) were determined. Body temperature, pulse and respiration rates were measured twice daily at 8:00 and 15:00 hr.

Data were statistically analyzed according to SAS (1986). Means were separated using Duncan's multiple range test if the mean effect of treatments was significant.

\section{RESULTS AND DISCUSSION}

Feeding high concentrate ration resulted in higher $(\mathrm{P}<.01)$ nutrient digestibilities except for crude fiber (Table 2). The low CF digestibility might be due to the negative associative effect due to the higher proportion of concentrates in low roughage diet (Mould et al., 1983; Oliveros et al., 1989 and El-Bedawy et al. 1989).

Heat stress decreased $C F$ digestibility without significant effect on the other nutrient 
digestibilities. Greater decrease in CF digestibility by heat stress was more drastic in high roughage diet (from 55.38 to 40.51 ) compared with that of low roughage one (from 41.71 to 37.10 ). Christopherson and Kennedy (1983) concluded that the digestibility of forage diet characterized by low fermentation rate is more affected by temperature-induced change in motility and the rate of passage of digesta compared with rapidly fermented concentrates.

Table 2. Effect of roughage level and environmental temperature on nutrient digestibilities and nutritive value by sheep fed at maintenance

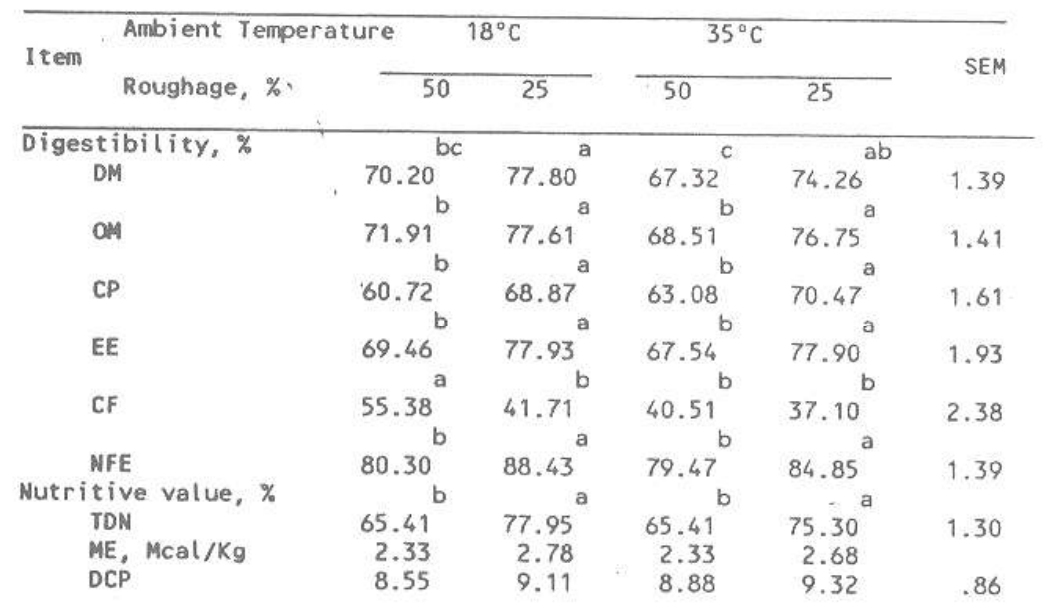

$\overline{a, b, c}$ Means in the same line with different superscripts differ $(P<.01)$.

Moreover, Roy et al. (1969 and Bhattacharya and Hussain 1974 attributed the decrease in nutrient digestibility associated with heat stress to the high water consumption of animals under high environmental temperature which enhanced passage of the digesta and/or have dilute the microbial population hindering substrate- enzyme contact. However, slight increase in nutrient digestibilities due to heat stress was reported by Blaxter et al. (1959) and Graham et al. (1959). Such contradicted results were attributed to the confounding of temperature condition and the variation in feed intake and the possible selective refusal of some 
components of the diet (Christopherson and Kennedy, 1983). The Factor of selective refusal was eliminated in the present study by the restricted feed intake at the maintenance level.

Feeding high roughage diet resulted in a slight increase in water consumption by sheep under low environmental temperature (11\%) but with greater increase under high ambient temperature by about $20 \%$ (Table 3 ). When water consumption was corrected to the dry matter intake and calculated as L/Kg DM intake, water consumption was almost similar whatever the change in roughage level under the two conditions of ambient temperature. The stimulating effect of high roughage diet on water consumption might be related to that roughage diets induce secretion of large volumes of saliva depending on quantity and dry matter content of feed eaten (Scott, 1975).

Table 3. Effect of dietary roughage level and environmental temperature on water balance by sheep fed at maintenance

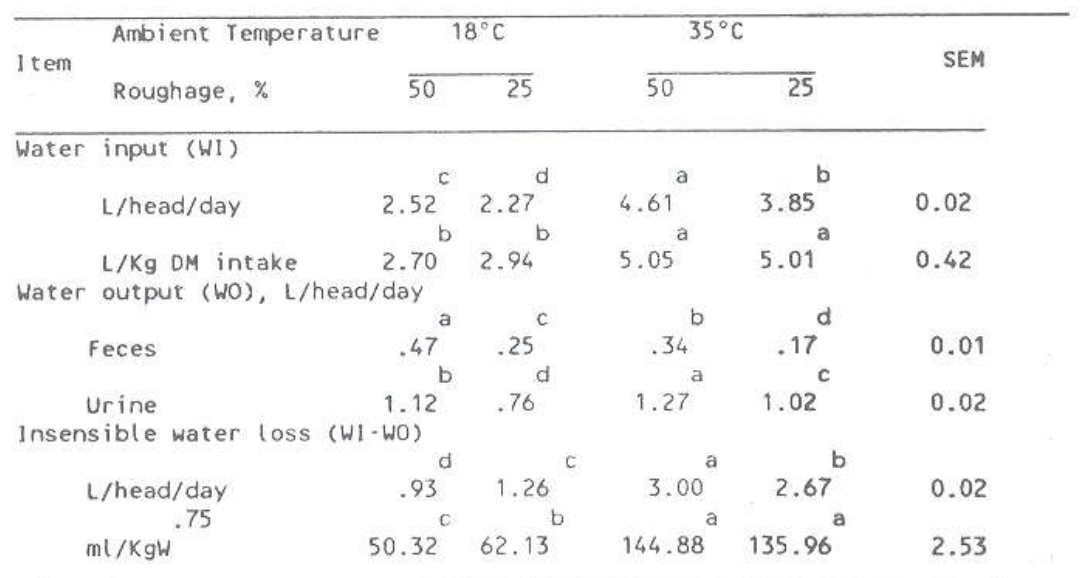

$a, b, c, d$ Means in the same line with different superscripts differ $(\mathrm{P}<.01)$

Heat stress caused significant $(\mathrm{P}<0.01)$ increase in water consumption as $\mathrm{g} /$ head/day or $\mathrm{L} / \mathrm{Kg} \mathrm{DM}$ intake especially when high roughage diet was fed. Almost similar results were found by Muna and Abdelatif (1992). It could be suggested from the present study that an 
increase of $1^{\circ} \mathrm{C}$ from $18^{\circ} \mathrm{C}$ to $35^{\circ} \mathrm{C}$ increased water consumption per $\mathrm{Kg}$ dry matter intake by 0.138 liter for low roughage and 0.122 liter for high roughage diets (Table 3).

Insensible water loss was $(\mathrm{P}<0.01)$ higher under heat stress for both roughage level. The low Insensible water 1088 by sheep fed high roughage diet under $18^{\circ} \mathrm{C} \mathrm{might} \mathrm{be}$ related to their relative higher water loss in feces and urine.

Fecal water loss was $(\mathrm{P}<0.01)$ lower under heat stress. However, heat stress resulted in higher $(\mathrm{P}<0.01)$ urinary and insensible water losses particularly with low roughage diet. It is clear that animals under heat stress increased water consumption and vaporized water (ingensible water loss) to utilize the thermoregulatory action of water. Vaporized water is the main carrier of heat dissipation via panting and sweating (Wilson 1974; Saxena and singh 1983). Feeding high concentrate diet increased ( $P<0: 01$ ) ruminal ammonia-N but decreased buffering capacity with no significant effect on molar proportions of ruminal VFA, protozoa or rumen fluid volume (Table 4 ).

Table 4. Effect of dietary roughage level and environmental temperature on rumen parameters of sheep fed at maintenance

\begin{tabular}{|c|c|c|c|c|c|}
\hline \multirow[t]{2}{*}{ Ambient Temperature } & \multicolumn{2}{|c|}{$18^{\circ} \mathrm{C}$} & \multicolumn{2}{|c|}{$35^{\circ} \mathrm{C}$} & \multirow{2}{*}{ SEM } \\
\hline & 50 & 25 & 50 & 25 & \\
\hline & c. & a & $\mathrm{b}$ & a & \\
\hline \multirow{3}{*}{$\begin{array}{l}\text { Ammonia-N, mg/100 mi } \\
\text { VFA's m.eq. } / 100 \mathrm{mt}\end{array}$} & 15.28 & 34.2 & 26.5 & 33.4 & 1.67 \\
\hline & 9.62 & 9.62 & 11.25 & 9.71 & .76 \\
\hline & bc & & a & $a b$ & \\
\hline \multirow[t]{2}{*}{ Acetate, $\%$} & 50.16 & 48.71 & 55.36 & 53.55 & .92 \\
\hline & a & b & b & b & \\
\hline Propionate, $\%$ & $\begin{array}{r}32.38 \\
\mathrm{c}\end{array}$ & $\begin{array}{r}20.92 \\
a\end{array}$ & 21.98 & $\begin{array}{l}21.48 \\
a b\end{array}$ & 1.28 \\
\hline Butyrate, $\%$ & $\begin{array}{r}17.48 \\
b\end{array}$ & $\begin{array}{r}30.37 \\
\text { a }\end{array}$ & $\begin{array}{r}22.66 \\
a\end{array}$ & $\begin{array}{r}24.97 \\
a\end{array}$ & 1.65 \\
\hline \multirow{3}{*}{$\begin{array}{l}\text { Acetate: propionate ratio } \\
\text { Rumen temperature } \\
\text { pH }\end{array}$} & 1.57 & 2.37 & 2.52 & 2.49 & 0.11 \\
\hline & 38.62 & 38.60 & 38.77 & 38.75 & 0.12 \\
\hline & $\begin{array}{r}6.40 \\
a\end{array}$ & $\begin{array}{r}6.17 \\
b\end{array}$ & $\begin{array}{r}6.32 \\
a b\end{array}$ & $\begin{array}{r}6.20 \\
c\end{array}$ & 0.14 \\
\hline \multirow{2}{*}{$\begin{array}{l}\text { Buffering capacity } \\
\text { Protozoa count }\end{array}$} & 99.5 & 82.1 & 89.2 & 63.2 & 3.9 \\
\hline & $\begin{array}{c}1.056 \\
b\end{array}$ & $\begin{array}{r}1.174 \\
b\end{array}$ & $\begin{array}{r}.802 \\
a\end{array}$ & $\begin{array}{r}.724 \\
a\end{array}$ & .177 \\
\hline Rumen fluid volume & 2.61 & 2.46 & 3.58 & 3.38 & 0.06 \\
\hline
\end{tabular}

$a, b, c$ Means in the same line with different superscripts differ $(P<.01)$ 
High ambient temperature decreased $(\mathrm{P}<.01)$ buffering capacity and protozoa count, with no significant effect on ammonia-N concentrations and molar proportions of propionate or butyrate. The heat stress increased $(\mathrm{P}<.01)$ rumen fluid volume, acetate and acetate: propionate ratio Rumen fluid $\mathrm{pH}$ and temperature. Total VFA's concentrations were not affected significantly by either roughage level or ambient temperature (Table 4). High ambient temperature was reported to decrease all ruminal volatile fatty acids (Gengler et al. 1975).

When VFA's concentrations were corrected to the rumen fluid volume (VFA's meq. $/ L \times$ rumen fluid volume, L), the averages were 251 and $236 \mathrm{meq}$. under $18^{\circ} \mathrm{C}$ versus 402 and $328 \mathrm{meq}$. under $35^{\circ} \mathrm{C}$ with high and low roughage diet, respectively.

Thermo-cardio-respiratory responses (Table 5) showed that increasing roughage level $(\mathrm{P}<.01)$ increased rectal temperature but decreased $(\mathrm{P}<.01)$ pulse rate and respiration rate. However, high ambient temperature had raised $(\mathrm{P}<.01)$ rectal temperature, and respiration rate and $(\mathrm{P}<.05)$ pulse rate. The effect of high roughage diet was more evident with the high ambient temperature on rectal temperature and respiration rate but not on pulse rate as indicated by the significant roughage and ambient temperature interaction on rectal temperature and respiration rate. Almost similar effects of hot climate on these parameters were documented by McDowell and Woodward (1982) that increasing ambient temperature for sheep from thermal neutral zone to $40^{\circ} \mathrm{C}$ increased rectal temperature from 39.5 to $40^{\circ} \mathrm{C}$, pulse rate from 73 to 97 and respiration rate from 22 to 275 per minute.

It could be concluded that high feeding high roughages under high environmental temperature aggravated heat dissipating mechanism in sheep as indicated from the highest values of water intake, urinary water loss, insensible water loss, pulse rate and respiration rate.

Moreover, the less drastic changes in
Thermo-cardio-respiratory

response of sheep in the present study compared with that observed by McDowell and Woodward (1982) could indicate that the local sheep are more adapted to hot stress conditions. 


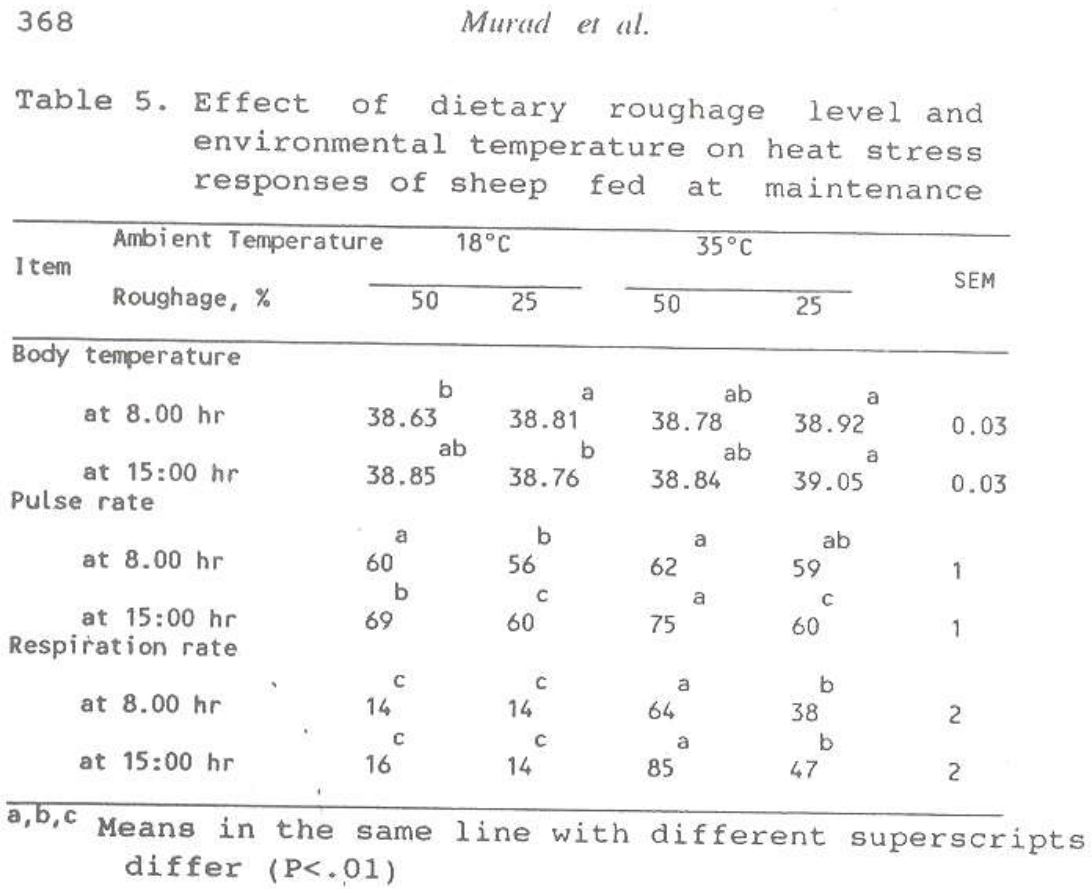

\section{REFERENCES}

A.O.A.C., 1975. Official Methods of Analysis (12th Ed.) Associattion of Official Analytical Chemists, Washington, DC.

Bhattacharya, A. N, F. Hussain, 1974. Intake and utilization of nutrients in sheep fed different levels of roughage under heat stress. J. Anim. Sci. 38:877.

Blaxter, K.L., N.MCC. Graham and F.M. Wainman, 1959. Environmental temperature, energy metabolism and heat regulation in sheep. III- The metabolism and thermal exchange of sheep with fleeces. J. Agric. Sci. Camb. 52:41.

Chaiyabuter, N., C. Burankarl, V. Muangcharon, P. Loypetjra, and A. Pichaicharnarong, 1987. Effect of acute heat stress on changes in the rate of liquid flow from the rumen and turnover of body water of swamp buffalo. J. Agric. Sci. Camb., 108: 549 .

Christopherson, R.J. and P.M. Kennedy, 1983. Effect of thermal environment on digestion in ruminants. Can. J. Anim. Sci. 63:477 (Abstr.). 
Conway, E. J., 1962. Microdiffusion Analysis and VolumetricError. (5th Ed.). Crosby Lockwood and Sons Ltd., London.

El-Bedawy, T.M., M.A. Hanafy and A. Higazy, 1989. Effect of feeding all-barley diet with or without sodium bicarbonate on

physiological and productive performance of dairy goats. Third Egyptian-British Conference on Animal, Fish and Poultry Production. Alexandria, 7-10 October, 1989.

El-Saifi, A. A., 1969. The diagnostic value of ruminal juice examination of cases of indigestion in buffaloes. M.D. Vet. Thesis, Fac. of Vet. Medicine, Cairo University.

Erwin, E. S., G.J. Marco, and E.M. Emery, 1961. Volatile fatty acids analysis of blood and rumen fluid by gas chromatography. J. Dairy Sci. 44:1768.

Gengler, W.R. F.A. Martz, H.D. Johnson, G.F. Krause, and L. Nahn, 1975. Effect of temperature on food and water intake and rumen fermentation. J. Dairy Sci. $53: 434$.

Graham, N. MCC. F.M. Wainman, K.L. Blaxter, and D.G. Armstrong, 1959. Environmental temperature, energy metabolism and heat regulation in sheep. J. Agric. Sci. Camb. 52:13.

Kromann R. P., J.H. Meyer, and W.J. Stielau, 1967. Steem distillation of volatile fatty acids in rumen digesta. J. dairy Sci. 50:73.

Mangan, J. L. and P.C. Wright, 1968. The rumen volume of sheep and cattle with lithium salts. Res. Vet. Sci. 9: 366 .

MCDowell, R.E. and A. Woodward, 1982. Concepts in animal adaptation- Comparative suitability of goats, sheep and cattle to tropical environments. Proceeding of $3 \underline{r d}$ International Conference Goat Production and Disease. Tucson, Arisona, USA. pp 387.

Mouna, M.M.N. and A.M. Abdelatif, 1992. Utilization of nutrients by sheep as affected by diet composition and solar radiation. Small Rumin. Res. 9:37.

Mould, F. L., E.R. Orskov, and S.O. Mann, 1983. Associative effects of mixed feeds. 1. Effects of type and level supplementation and the influence of rumen fluid pH on celluloysis in vivo and dry matter digestion of various roughages. Anim. Feed 
Sci. and Technol., 10;15.

Nicholson, J.W. G., R.E. McQueen, and P.L. Burgess, 1963. The addition of buffers to ruminant rations. 4- The effect of additions of sodium bicarbonate, sodium propionate, limestone and cod liver oil on interrumen environment. Canadian J. Anim. Sci. $42: 309$.

NRC, 1975. Nutrient Requirements of Domestic Animals. No. 5- Nurient requirements of sheep. 5 th rev. ed., National Research Council, Washingtonn, DC.

oliveros, B. A., T.J. Klopfenstein, M.L. Goedeken, M.L. Nelson and E.E. Hawkins, 1989. Corn fiber as an energy supplement in high-roughage diets fed to steers and lambs. J. Anim. Sci. 67:1784.

Roy, M., V.N. Roa and D.P. Sadhu, 1969. Effect of climate on the metabolism of proximate nutrients in growing growing Hariana cattle. Metabolism of proximate principles. Ind. J. Dairy Sci. 22:248.

Saxena, S.K. and K. Singh, 1983. Water turnover rates in Hariana cattle and their crosses at different temperatures. Indian J. Anim. Sci. 53:944.

SAS Users guide: Statistics.1982. SAS Inst. Cary, NC.

Scott, D., 1975. Changes in mineral, water and acid-base balance associated with feeding and diet. Digestion and Metabolism in the Ruminanat. The University of New England Publishing Unit, Armidale, N.S.W. 2351, Australia.

Wilson A. D., 1974. Water consumption and water turnover of sheep grazing semi-arid pasture in warm environments. J. Agric. Sci. Camb. 78:413. 


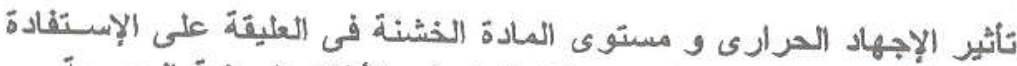

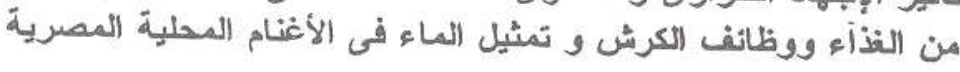

همــدى محمد مـراد - طله محمد البداوى - محمد محمود الثـافعى سـالم محمد سالم

قسم الإنتاج الحيو انى، كلية الزر اعة، جامعة القاهرة، الجيزة، مصر

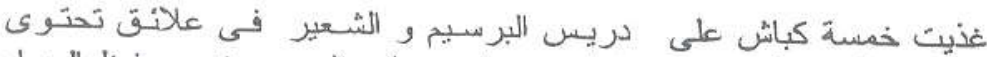

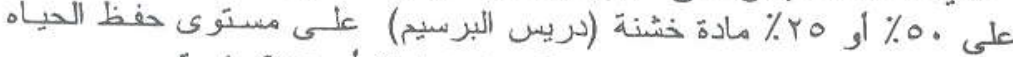

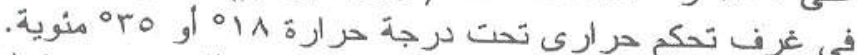

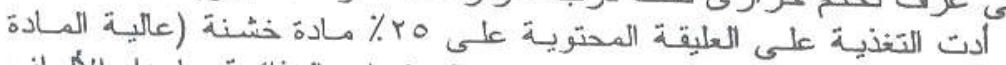

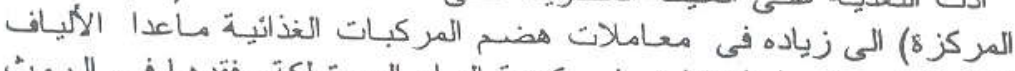

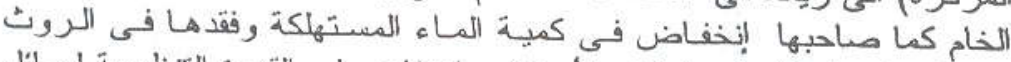

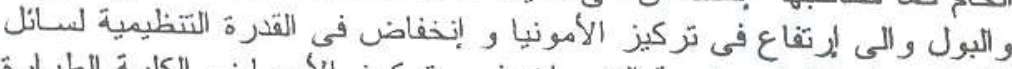

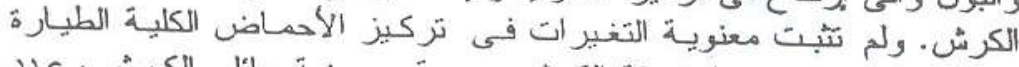

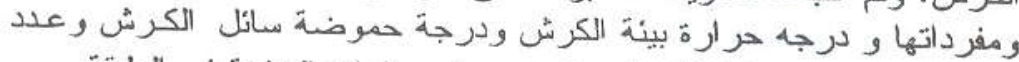

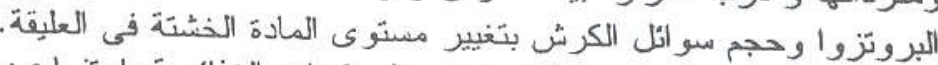

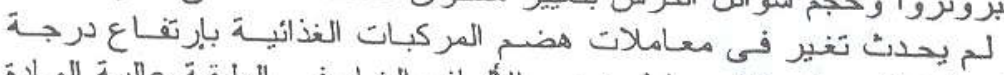

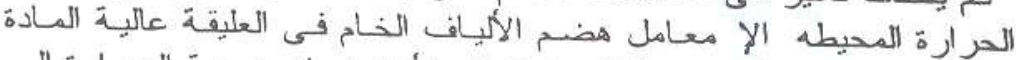

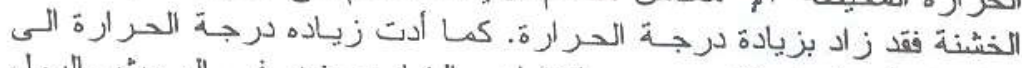

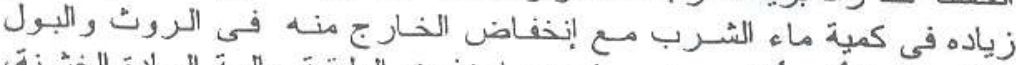

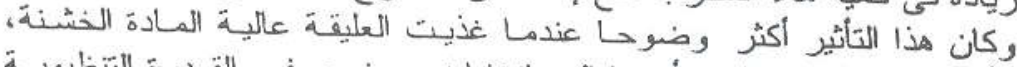

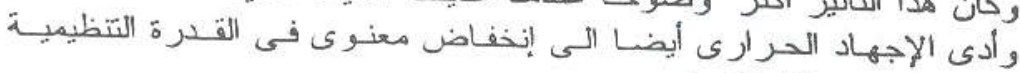
وزياده حجم سائل الكرش.

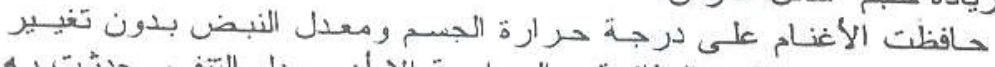

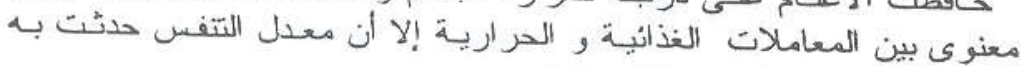
زيادة كبيرة تحت ظروف الإجهاد الحرارى. 